\title{
Prescribing Skills of First and Second Year MBBS Students of A Teaching Hospital
}

\author{
Kumud Chapagain, ${ }^{1}$ Bhaskar Diwakar Paranjape, ${ }^{1}$ Ganesh Lama ${ }^{2}$ \\ 'Department of Clinical Pharmacology, Nobel Medical College Teaching Hospital, Biratnagar, Nepal, ${ }^{2}$ District Public Health \\ Office, Kathmandu, Nepal.
}

Introduction: To ensure safe, effective and rational prescribing by tomorrow's doctors it is important to assess the prescribing skills of today's medical students. The aim of this study was to assess the prescribing skills of MBBS preclinical students of a Teaching Hospital.

Methods: First and second year medical students were given different sets of common clinical scenarios and asked to write a prescription for these. The physician and drug related components were analyzed following the WHO guidelines. The data were statistically analyzed using Chisquare test for $99 \%$ and $99.99 \%$ Confidence Intervals. P values $<0.01$ and $<0.0001$ were considered significant respectively.

Results: MBBS first year student scored $123(82 \%)$ and $94(62.66 \%)$ in physician and drug related component respectively. MBBS second year students scored $139(92.66 \%)$ and $111(73.33 \%)$ in physician and drug related components respectively. Results obtained from the element prescriber's address and telephone number, date of prescription and patient's address on the prescription of first year and second year medical students were highly significant $(\mathrm{p}<0.0001)$.

Conclusions: Prescribing skill of first and second year MBBS students is not satisfactory. Prescribing deficiencies were found on both the physician and drug related components which emphasizes the need of adequate prescribing knowledge in order to minimize the prescription errors and irrational prescribing. Based on this study, we suggest all the undergraduate medical students should be regularly trained and evaluated to further help minimize the prescribing errors.

Keywords: prescription; prescription errors; prescribing skill.

\section{INTRODUCTION}

Medical students must acquire adequate prescribing competencies before they graduate. For safe, effective and rational drug prescribing, they should have adequate knowledge and skill. But is this the scenario around? Are the students well prepared to enter the clinical grounds and can rationally prescribe?

Rational drug prescribing means prescribing appropriate drug in adequate dose for sufficient duration at a reasonable cost to obtain the best possible effect. ${ }^{1}$ Medical students should be regularly trained and assessed on their prescribing knowledge and skills in order to promote rational drug prescribing. ${ }^{2,3}$ Awareness regarding prescribing errors today can improve the

Correspondence: Dr. Kumud Chapagain, Department of Clinical Pharmacology, Nobel Medical College Teaching Hospital, Biratnagar, Nepal. Email: kumudchapagain14@gmail.com, Phone: +977-9841390503. 
health care delivery system in future. However, rational prescribing still remains a teaching program related to the subject. ${ }^{4}$ In previous studies, it has been highlighted that the prescription writing skills of medical students are not satisfactory. ${ }^{5}$ It was quite apparent that only reasonable number of students were aware in every parts of physician and drug related components. ${ }^{4}$ Therefore the present study was conducted with an objective to assess the prescription writing skills of preclinical undergraduate medical students of Nobel Medical College Teaching Hospital, Biratnagar. The result of this study also gives room for effective changes in the existing process of teaching and learning activities in pharmacology.

\section{METHODS}

A cross-sectional study was carried out in the department of Clinical Pharmacology amongst first and second year MBBS students in the month of May and June 2016. All first and second year students were included in the study. After the ethical clearance from the Institutional Review Committee and obtaining verbal consent from the participants, the students were given different sets of common conditions / case scenarios by lottery methods. The case scenarios were chosen depending on the part of pharmacotherapy covered in their respective year of teaching. They were allotted 10 minutes to write the prescription for the conditions given to them. Their prescriptions were then assessed using preformed checklists for both the physician related and the drug related components.

The physician related component comprises of prescriber's identity, professional degree and registration no., prescriber's address, date of prescription, patient's identity, patient's address, the symbol Rx (Take Thou), diagnosis, information, instruction and warning to the patient and the prescriber's signature. ${ }^{6}$ The drug related components are appropriateness of drug(s) selected, strength of drug(s), dosage forms, quantity to be dispensed, and the direction for use. ${ }^{6}$ The principle author assessed each prescription using the checklists and accordingly score was given. The mean score rates for different components of prescriptions written by different years of students were also calculated. Each student's identity was kept anonymous. The observed data were expressed in number and percentage. Results obtained were statistically analyzed using Chi square test. $P$ values $<0.01$ and $<0.0001$ were considered significant and highly significant respectively.

\section{RESULTS}

The performance of prescription writing skill was assessed amongst a total no. of 300 students, of which 150 were in first year and 150 were in second year MBBS. Score of different parts of physician and drug related components of both $1^{\text {st }}$ and $2^{\text {nd }}$ year MBBS students (Table1).

\begin{tabular}{|c|c|c|}
\hline Components & \multicolumn{2}{|c|}{ Medical Students } \\
\hline \multirow[t]{2}{*}{$\begin{array}{l}\text { Physician related } \\
\text { components }\end{array}$} & $\begin{array}{l}\text { First Year } \\
(n=150)\end{array}$ & $\begin{array}{l}\text { Second Year } \\
(n=150)\end{array}$ \\
\hline & n (\%) & $\mathrm{n}(\%)$ \\
\hline Prescribers identity & $143(95.33)$ & $145(96.66)$ \\
\hline $\begin{array}{l}\text { Professional degree } \\
\text { and registration no: }\end{array}$ & $98(65.33)$ & $123(82)$ \\
\hline $\begin{array}{l}\text { Prescribers address } \\
\text { and telephone no: }\end{array}$ & $103(68.66)$ & $131(87.33)^{\dagger}$ \\
\hline Date of prescription: & $103(68.66)$ & $131(87.33)^{\dagger}$ \\
\hline Patients identity & $145(96.66)$ & $147(98)$ \\
\hline Patients address & $105(70)$ & $142(94.66)^{\dagger}$ \\
\hline Diagnosis & 146 (97.33) & $148(98.66)$ \\
\hline Symbol - Rx & $146(97.33)$ & $148(98.66)$ \\
\hline $\begin{array}{l}\text { Prescriber's } \\
\text { signature }\end{array}$ & 143 (95.33) & $148(98.66)$ \\
\hline $\begin{array}{l}\text { Information, } \\
\text { instructions and } \\
\text { warnings to patients }\end{array}$ & $91(60.66)$ & $112(74.66)^{*}$ \\
\hline \multicolumn{3}{|c|}{ Drug related components } \\
\hline $\begin{array}{l}\text { Appropriateness of } \\
\text { drug selected }\end{array}$ & $120(80)$ & $138(92)^{*}$ \\
\hline Strength of drug & $94(62.66)$ & $121(80.66)^{*}$ \\
\hline Dosage form & $98(65.33)$ & $103(68.66)$ \\
\hline $\begin{array}{l}\text { Quantity to be } \\
\text { dispensed }\end{array}$ & $58(38.66)$ & 72 (48) \\
\hline Direction for use & $102(68)$ & $114(76)$ \\
\hline
\end{tabular}

${ }^{*} P<0.01 ;{ }^{\dagger} P<0.0001$

The results reveal that MBBS undergraduate students performance score varies from highest 146 (97.33\%) to lowest $91(60.66 \%)$ among first year and from 148 $(98.66 \%)$ to $112(74.66 \%)$ in second year in physician related component (Table1). The percentage of prescription containing prescriber's identity, patients' identity, diagnosis, symbol $\mathrm{Rx}$ and the prescriber's signature was above $90 \%$ in students of both the years. The performance score for the patients' address was $142(94.66 \%)$ amongst the second year students whereas it was only 105 (70\%) i.e. below 90\% among first year students (Table 1). Thus, the second year students preformed better in mentioning the patients address than the first year student. The difference observed in this element was found to be statistically 
significant $(\mathrm{P}<0.0001)$. Among both year students', the most deficient part of physician related components were providing the information, instructions and the warnings to the patient (Table 1) followed by the professional degree and registration number. The differences of missing these two elements amongst the first year and the second year students were found to be statistically significant $(P<0.01)$.

The next deficient element among physician related components amongst first year student was prescribers address and telephone number. It was found to be only 103 (68.66\%) among them. However, this particular element was written by comparatively better number of second year students but still not up to the mark i.e. only $131(87.33 \%)$ and the difference is statistically highly significant $(P<0.0001)$.

Among the drug related components, the performance score ranged from lowest $58(38.66 \%)$ and 72 $(48 \%)$ among students of first year and second year respectively in the element quantity of drug to be dispensed. Similarly, performance score ranged from highest of $120(80 \%)$ and 138 (92\%) amongst students of first and second year respectively in the element appropriateness of drug selected. Students of both the year performed comparatively better for the element appropriateness of drug selected. The differences between the first and second year students in this element was statistically significant $(P<0.01)$.

In the comparison of both the physician and drug related component among the students, it is seen that second year students scored $92.66 \%$ and $73.33 \%$ in physician related and drug related components respectively (Table 2 ), which is better than the scores of first year students. The mean scores for the physician related components and the drug related components of first year students were $82 \%$ and $62.66 \%$ respectively (Table 2 ).

\begin{tabular}{|c|c|c|}
\hline \multicolumn{3}{|c|}{$\begin{array}{l}\text { Table 2. Comparison of mean scores of different } \\
\text { components of prescription. }\end{array}$} \\
\hline \multirow[b]{2}{*}{ Components } & First Year & Second Year \\
\hline & $\begin{array}{l}(n=150) \\
\%\end{array}$ & $(n=150) \%$ \\
\hline $\begin{array}{l}\text { Physician related } \\
\text { components }\end{array}$ & 82 & 92.66 * \\
\hline $\begin{array}{l}\text { Drug related } \\
\text { components }\end{array}$ & 62.66 & 73.33 \\
\hline
\end{tabular}

\section{DISCUSSION}

The results of this study reveal the prescription writing skills amongst preclinical MBBS students. It is quite apparent that a good number of students of both first and second year were unaware in every parts of physician and drug related components. Both the first and the second year students made more mistakes in drug related components. Our results show deficiency in the prescribing competencies. This may be because of the quality of the undergraduate pharmacotherapy teaching which is lecture based and theoretical and learning how to prescribe competently is difficult and thus chances of error occur. ${ }^{7}$ Implementation of extensive problem based learning approach may be more effective in this aspect. Also the inclusion of World Health Organizations' Guide to Good Prescribing ${ }^{1}$ into the medical curriculum would make a more focused approach to educating the students on prescribing.

In this study, the most common type of error was lack of information, instructions and warnings to the patient. This is consistent with the findings observed in the study conducted in a medical institute of Nepal. ${ }^{8}$ This element is important so as to ensure compliance and proper success of given therapy and is needed to be emphasized to prevent any adverse drug events related to the therapy.

Our study reveals the drug related components of prescriptions of students of both the years are deficient in the element quantity to be dispensed, dosage forms, strength of drug and direction for use. Previous study also remarks the consistent findings, i.e. lack of awareness about the drug posology. ${ }^{9}$ Various studies have revealed medical undergraduates lack confidence in writing prescriptions and are weak in the pharmacological knowledge. ${ }^{10-13}$ These improperly filled out prescriptions are common issues and are more liable to compromise on patients health and safety, thus, also to avoid this, inclusion of Guide to Good Prescribing into the medical curriculum is very essential and a need. Furthermore, the prescribing knowledge and skills of the undergraduate students should be assessed regularly and should be a part of summative assessment. By examining aspects of prescription writing that can cause errors and by modifying the prescription writing habits accordingly, the chance of patient receiving correct prescription can be ensured. Establishment of Medical Schools' Council (MSC) Safe Prescribing Working Group ${ }^{14}$ can also be thought by the governing bodies.

\section{CONCLUSIONS}

The knowledge of prescribing drugs, proper prescription writing skills following the WHO Six-step model of prescribing is very essential to minimize the prescription errors and irrational prescribing. Based on our study, we recommend all the undergraduate medical students and the outgoing students, tomorrow's doctors, should 
be included in this type of evaluation to further help minimize the prescribing errors.

Conflict of Interest: None.

\section{ACKNOWLEDGEMENTS}

We thank all medical students who participated in this study.

\section{REFERENCES}

1. de Vries TPGM, Henning RH, Hogerzeil HV, Fresle DA. Guide to Good Prescribing: a practical manual. Geneva: World Health Organisation, Action Programme on Essential Drugs, 1994. Cited 2016 Dec 5. Available from: URL:http:// apps.who.int/medicinedocs/pdf/whozip23e/whozip23e. pdf

2. Jain A, Gupta D, Singh D, Garg Y, Saxena A, Chaudhary H, et al. Knowledge regarding prescription of drugs among dental students: A descriptive study. J Basic Clin Pharma. 2016;7:12-6.

3. Kia SJ, Behravesh M, Sigaroudi AK. Evaluation of Drug Prescription Pattern among General Dental Practitioners in Rasht, Iran. Journal of Dentomaxillofacial Radiology, Pathology and Surgery. 2013;1:18-23.

4. Rauniar GP, Roy RK, Das BP, Bhandari G, Bhattacharya SK. Prescription Writing Skills of Pre-Clinical Medical and Dental Undergraduate Students. J Nepal Med Assoc. 2008;47:197-200.

5. Khaja KAJA, Handu SS, James $\mathrm{H}$, et al. Assessing prescription writing skills of pre-clerkship medical students in a problem-based curriculum. Int J Clin Pharmacol Ther. 2005; 43(9): 429-35.

6. Lofholm PW, Katzung BG: Rational prescribing and prescription writing: In Katzung BG editor. Basic and Clinical Pharmacology. New York: McGraw-Hill; 2001. p.1104-113.

7. Audit Commission. A Spoonful of Sugar-[Improving Medicines Management in Hospitals.] London: Audit Commission, 2001. Cited 2016 Dec 5. Available frm: URL:http://www.auditcommission. gov.uk/ re port s / N A T I O N A LREPOR T. asp? CategoryID=\&ProdID=E83C8921-6CEA-4b2c-83E7F80954A80F85
8. Kumar J, Shaile MM, Kathi MC, Chetty MS, Deka A. Appraisal of prescription writing skills of preclinical undergraduate students of Nepal. J Coll Med Sc. 2010;6(4):7-13.

9. Guzman Alvarez R, Medeiros M, Reyes Lagunes LI, Campos Sepulveda AE. Knowledge of drug prescription in dentistry students. Drug, Healthcare and Patient Safety. 2012:4 55-59

10. Tobaiqy M, McLay J, Ross S. Foundation year 1 doctors and clinical pharmacology and therapeutics teaching. A retrospective view in light of experience. Br J Clin Pharmacol. 2007;64:363-72.

11. Heaton A, Webb DJ, Maxwell SR. Undergraduate preparation for prescribing: the views of 2413 UK medical students and recent graduates. Br J Clin Pharmacol. 2008;66:128-34.

12. Wall D, Bolshaw A, Carolan J. From undergraduate medical education to pre-registration house officer year: how prepared are students? Med Teach. 2006;28:435-9.

13. Illing J, Morrow G, Kergon C, Burford B, Spencer J, Peile $\mathrm{E}$, et al. How prepared are medical graduates to begin practice? A comparison of three diverse UK medical schools. Final summary and conclusions for the GMC Education Committee. 15th December 2008. Cited 2016 Dec 5. Available from: URL:http://www.gmc-uk.org/FINAL How prepared are medical graduates to begin practice. September 08.pdf 29697834

14. Lechler R, Paice E, Hays R, Petty-Saphon K, Aronson J, Bramble M, et al. Outcomes of the Medical Schools Council Safe Prescribing Working Group. November 2007. Cited 2016 Dec 5. Available from: URL:http://www.medschools. ac.uk/ Publications/Pages/Safe-Prescribing-WorkingGroupOutcomes.aspx 